\title{
Carpal tunnel syndrome in manual tea harvesters
}

\author{
Elle yapılan çay tarımı işçilerinde karpal tünel sendromu
}

\author{
Mert Çiftdemir, M.D., ${ }^{1}$ Cem Çopuroğlu, M.D., ${ }^{1}$ Mert Özcan, M.D., ${ }^{1}$ Leyla Çavdar, M.D. ${ }^{2}$ \\ 'Department of Orthopedics and Traumatology, Medical Faculty of Trakya University, Edirne, Turkey \\ ${ }^{2}$ Department of Neurology, Of State Hospital, Trabzon, Turkey
}

\begin{abstract}
Objectives: This study aims to present the physiopathological and surgical aspects of carpal tunnel syndrome (CTS) related to manual tea harvesting based on nerve conduction studies and clinical scoring systems.
\end{abstract}

Patients and methods: Clinical and neurophysiological scores as well as clinical and occupational variables were statistically analyzed using Boston questionnaire, modified criteria of Italian CTS study group, and modified neurophysiologic grading system of Italian CTS study group in 56 agricultural laborers who underwent surgery due to severe CTS.

Results: A statistically significant correlation was found among the clinical stages of the patients and age, working duration and duration of symptoms. There was a statistically significant relationship among neurophysiologic grades of the CTS in patients and the duration of symptoms and functional outcomes before and after surgery.

Conclusion: We concluded that manual tea harvesting might be an occupational risk factor for work-related CTS development. Surgical treatment of CTS among manual tea harvesters revealed satisfactory results.

Key words: Agricultural workers' diseases; carpal tunnel syndrome; nerve compression syndromes; surgical procedures, minor; tea.

Carpal tunnel syndrome (CTS) is the most common entrapment neuropathy in humans. ${ }^{[1]}$ It is also a part of the cumulative trauma disorders. ${ }^{[2]}$ Although many clinical risk factors are associated with the syndrome, epidemiologic studies have identified that several combinations of work factors, individual factors, and psychosocial factors are also related to CTS. The incidence of CTS has been estimated at $1 \%$
Amaç: Bu çalışmada elle yapılan çay tarımına bağlı karpal tünel sendromunun (KTS) fizyopatolojik ve cerrahi boyutu, sinir ileti çalışmaları ve klinik skorlama sistemleri kullanarak değerlendirildi.

Hastalar ve yöntemler: Şiddetli KTS nedeniyle cerrahi tedavi uygulanan 56 tarım işçisinin klinik ve nörofizyolojik skorları ile klinik ve mesleki değişkenleri; Boston anketi, İtalyan KTS çalışma grubunun modifiye kriterleri ve İtalyan KTS çalışma grubunun modifiye nörofizyolojik evreleme sistemi kullanılarak istatistiksel olarak değerlendirildi.

Bulgular: Hastaların klinik evreleri, yaşları, toplam çalışma süreleri ile semptomların süresi arasında anlamlı istatistiksel ilişki bulundu. Hastalardaki KTS'nin nörofizyolojik evreleri ve semptomların süresi ile cerrahi tedavi öncesi ve sonrasında fonksiyonel sonuçlar arasında da anlamlı bir istatistiksel ilişki saptand1.

Sonuç: Elle yapılan çay tarımının mesleğe bağlı KTS gelişimi için mesleki bir risk faktörü olabileceği düşünüldü. Bu alanda çalışan isçilerde KTS'nin cerrahi tedavisi ile tatminkar sonuçlar elde edildi.

Anahtar sözcükler: Tarım isçileri hastalıkları; karpal tünel sendromu; sinir basısı sendromları; cerrahi uygulamalar, küçük; çay.

in the general population and 5\% among workers in certain industries requiring repetitive hand and wrist use. ${ }^{[3]}$

Many physical factors such as repetition, force, posture, vibration, cold environment and pressure have been considered as possible risk factors for work related CTS. ${ }^{[4]}$

- Received: March 12, 2012 Accepted: November 13, 2012

- Correspondence: Mert Çiftdemir, M.D. Trakya Üniversitesi Tıp Fakültesi Ortopedi ve Travmatoloji Anabilim Dalı, 22030 Edirne, Turkey. Tel: +90 532 - 7653385 Fax: +90284-2133899 e-mail: dr.mert@gmail.com 
Manual tea harvesting requires repetitive and powerful use of wrist extensor muscles and finger flexor muscles while harvesting tea with a tool called tea scissors, and appears to be a specific risk factor for work related CTS (Figure 1). Several studies about occupational factors and CTS are present in the literature. ${ }^{[1,5-10]}$ Among the occupational factors having a role in the CTS etiology, manual tea harvesting has not yet been investigated. Clinical and neurophysiological evaluation of CTS among manual tea harvesters, and results of open carpal tunnel release as surgical treatment were investigated in this study. The aim of this study was to present the clinical and diagnostic aspects and results of surgery regarding CTS related to manual tea harvesting based on nerve conduction studies and clinical scoring systems.

\section{PATIENTS AND METHODS}

Fifty-six agricultural laborers ( 3 males, 53 females; mean age $50 \pm 9.9$ years; range 23 to 69 years) working in tea fields that underwent open carpal tunnel release (OCTR) due to neurophysiologically confirmed severe CTS between June 2006 and October 2008 were included in this study.

Patients were chosen from the patient group of 204 patients working as seasonal agricultural laborers in tea fields, admitted to the orthopedic outpatient clinic of a district hospital between June 2006 and October 2008 with classic symptoms of CTS including burning and numbness causing sleep disturbance which appear or increase in the tea harvesting period of the season. Twelve patients with previous upper extremity trauma, pregnancy, and accompanying musculoskeletal, neurological and endocrine disorders were excluded from the study. All of the remaining patients $(n=192)$

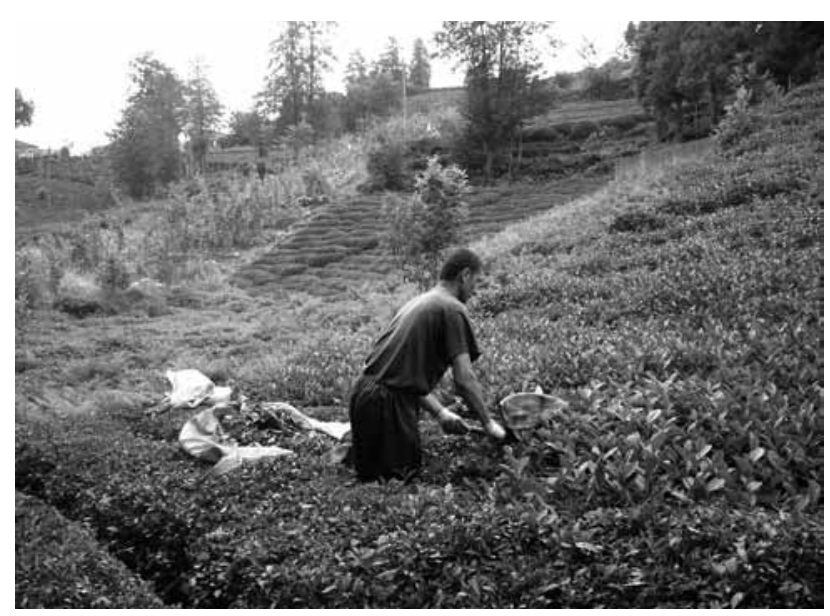

Figure 1. Posture and position of upper extremities during manual tea harvesting: Slightly bent forward with elbows in flexion, wrists in extension and strong handgrip with fingers in flexion. were clinically evaluated and assigned into mild and severe groups according to the modified criteria of the Italian CTS study group. ${ }^{[10,11]}$ Open carpal tunnel release was indicated only for severe cases $(n=56)$. Mild cases were treated non-operatively using non-steroidal anti-inflammatory drugs, B-complex vitamins with activity restraint and also excluded from the study.

The age, gender, extremity involvement and dominance, amount of the years spent working in the tea fields, duration of the symptoms and physical examination details for the patient group were recorded. All of the patients were asked to fill out the Boston questionnaire preoperatively. ${ }^{[12,13]}$ Symptom severity scores and functional status scores calculated from the Boston questionnaire at the preoperative period were recorded. Plain radiographs of the wrist and cervical spine were evaluated as normal in the entire patient group.

All patients underwent neurophysiological examination with electromyography (EMG) in the preoperative period. A single neurologist using the same EMG device performed all of the neurophysiological examinations. Sensory and motor nerve conduction studies of bilateral median and ulnar nerves were performed in all patients. Diagnosis of CTS was based on presence of at least one of these findings; abnormal sensory nerve conduction velocity in any finger-wrist segment, abnormal sensory nerve conduction velocity in palmwrist segment and prolonged motor distal latency in any segment. All of the neurophysiologic data were assessed according to the modified neurophysiologic grading system developed by Padua et al. ${ }^{[11]}$

After the neurophysiologic evaluation, one surgeon performed all operations under local anesthesia and pneumatic tourniquet via palmar approach starting from the distal wrist crease and extending distally to Kaplan's cardinal line along the axis at the radial border of the ring finger ${ }^{[14]}$ Bilateral OCTR was performed in six (11\%) and unilateral OCTR was performed in $50(89 \%)$ patients. The mean duration of surgery was 40 (range; 25-70) minutes. Median nerves were decompressed by excising the transverse carpal ligament in all patients. All patients were discharged from the hospital the next day after surgery. No early and late complications were seen in any patient. There were no limitations for the patients in the postoperative period except hard work. The patients were encouraged to start active wrist and finger exercises from the first postoperative day.

All patients were asked to fill out the Boston questionnaire again at the first postoperative month 
follow-up. Symptom severity scores and functional status scores in the postoperative period were also recorded. All patients were allowed to return to hard work after the sixth postoperative week and followed up to six months.

The overall data collected from the patient group were analyzed statistically. Definitive statistics were given as means and standard deviations (SD). Variance analysis was used for comparing the independent variables between the groups. Spearman correlation coefficient was calculated for testing the interaction for the variables not having normal distribution and Pearson correlation coefficient was calculated for testing the interaction of the variables having a normal distribution. Level of statistical significance was set at $\mathrm{p}<0.05$.

Informed consent to participate in the study was obtained from the participants. The study received ethical approval at 13/06/2012 (number: TÜTFTÜBADK 2012/137) from the Ethics Committee of the Trakya University Faculty of Medicine.

\section{RESULTS}

Sixty-two median nerves of 56 patients were decompressed with OCTR in our study. Dominant extremity involvement was found in 32 patients (57\%). Bilateral involvement was present in six patients $(11 \%)$, with 27 (48\%) right and 23 (41\%) left side involvement. The mean amount of years spent working in tea fields, shown as working duration in Table I was 33.5 \pm 9.8 years and the mean duration of symptoms was $23 \pm 12$ months. General characteristics of the patients are shown in Table I.

Phalen's test was positive in $52(93 \%)$, reverse Phalen's test was positive in 54 patients (97\%). Tinel's sign was positive in 51 hands (82\%), interosseous and thenar atrophy was present in 31 hands (50\%). Burning and numbness causing sleep disturbance was present in all patients. Variable sensory disturbances were present in all patients, especially in the distal web space pattern. ${ }^{[15]}$ Hypoesthesia was present in 51 hands $(82 \%)$, while 36 hands $(58 \%)$ had anesthesia at the tips of the fingers. Hypoesthesia at the first web space was present in 49 hands (79\%).

The modified criteria of the Italian CTS study group were used for clinical staging in our study. ${ }^{[10,11]}$ According to these criteria, only severe cases (stage III, IV and V) were included in our study group. Of the severe cases, 39 patients (70\%) were classified clinically as stage III and 17 patients (30\%) were classified as stage IV. There was no stage $\mathrm{V}$ patient in our study group.
Neurophysiological findings of the patients were evaluated according to the modified neurophysiologic grading system developed by Padua et al. ${ }^{[10]}$ There was no grade 0 and grade I hand according to neurophysiologic grading, grade II CTS was diagnosed in 12 hands $(19.3 \%)$, grade III CTS was diagnosed in 32 hands $(51.6 \%)$, grade IV CTS was diagnosed in 16 hands (25.8\%) and grade V CTS was diagnosed in two hands (3.2\%). The median nerve distal motor latency studies were prolonged in $32(97 \%)$ of the right and $28(96 \%)$ of the left hands. The median nerve sensory conduction studies were abnormal in $25(75 \%)$ of the right hands and $22(76 \%)$ of the left hands.

Statistically significant positive correlations were found between the clinical stages of the patients and the age, working duration and duration of symptoms. A statistically significant positive correlation was also present between the neurophysiologic grades of the patients and the duration of symptoms (Table II).

Functional outcomes of the patients were evaluated using the Boston questionnaire at the preoperative and the postoperative period. A statistically significant decrease was found between the preoperative and the postoperative results of the Boston questionnaire $(\mathrm{p}<0.001)$. The mean functional status score decreased from $2.93 \pm 0.42$ to $1.34 \pm 0.20$ and the mean symptom severity score decreased from $2.92 \pm 0.50$ to $1.48 \pm 0.22$ at one-month follow-up.

\section{DISCUSSION}

Carpal tunnel syndrome is a common health problem, which is often admitted as a work related condition. Carpal tunnel syndrome is shown to have a higher incidence rate in employed patients than in unemployed persons. ${ }^{[2,3,7,16-19]}$ It has been shown that occupational exposure to excess vibration, increased hand force and

\section{TABLE}

General characteristics of the patients $(n=56)$

\begin{tabular}{lccc}
\hline & $\mathrm{n}$ & $\%$ & Min.-Max. \\
\hline Age (years) & 50 & & $23-69$ \\
Gender & & & \\
$\quad$ Female & 53 & 95 & \\
$\quad$ Male & 3 & 5 & \\
Working duration (years) & & & \\
$\quad$ Duration of symptoms (months) & 33.5 & & $11-54$ \\
Involvement & 23 & & $8-60$ \\
$\quad$ Dominant & 32 & 57 & \\
$\quad$ Non dominant & 18 & 32 & \\
$\quad$ Bilateral & 6 & 11 & \\
\hline
\end{tabular}

Min.: Minimum; Max.: Maximum. 
TABLE II

The correlations between the clinical grades, neurophysiological grades, age, working duration and the duration of symptoms

\begin{tabular}{lccrrr}
\hline & \multicolumn{2}{c}{ Clinical stages } & & \multicolumn{2}{c}{ Neurophysiological grades } \\
\cline { 2 - 3 } & Correlation coefficient & $p$ & & Correlation coefficient & $p$ \\
Age (years) & 0.345 & 0.009 & & 0.211 & 0.119 \\
Working duration (years) & 0.409 & 0.002 & & 0.241 & 0.073 \\
Duration of symptoms (months) & 0.335 & 0.012 & & 0.271 & 0.043 \\
\hline
\end{tabular}

repetition increases the risk of developing CTS in a meta-analysis investigating the relationship between CTS and occupation. ${ }^{[20]}$ Lengthy exposure to high repetitive hand and wrist movements, high range wrist action, constant extreme wrist position, using handheld vibrating tools, work involving frozen food and availability of protection have been shown to be the key occupational points to consider in determining work liability for CTS. ${ }^{[21]}$

Flexor tenosynovitis and thickening of the transverse carpal ligament are thought to be responsible pathophysiologic factors for work-related CTS. Schuind et al. ${ }^{[22]}$ found the combination of fibrous hypertrophy, focal necrosis and serous bursae with no obviously inflammatory cells and surmised that repeated trauma due to friction of excessive flexor tendon movement caused tenosynovial fibrous degenerative hypertrophy. The amount of extraneural pressure within the carpal tunnel has been shown to be higher in patients with CTS, compared to the normal population in various studies. ${ }^{[23]}$ Manual tea harvesting is an important agricultural activity and the greater source of income in particular geographical regions. The laborers manually harvesting tea have to work for long periods performing repetitive and powerful hand and forearm movements in a static posture with a bilateral strong handgrip. We believe that prolonged non-neutral wrist position and finger loading due to strong handgrip during manual tea harvesting increase extraneural pressure and cause compression of the median nerve causing CTS.

Nearly $80 \%$ of the patients in our study group had moderate to severe CTS in terms of EMG grading, and prolonged motor terminal latency was significantly present with abnormal sensory nerve conduction. Predominance of the distal web space pattern sensory disturbance and hypoesthesia at the first web space were also significant clinical findings in our study group. Predominance of prolonged motor distal latency and hypoesthesia at the first web space may be indicative of motor fascicular involvement, which is may be related to flexor tenosynovitis. Sparing of the motor fascicles and hypoesthesia at the first web space is often seen in idiopathic CTS. These electrophysiological and clinical findings suggest extensive fascicular involvement within the median nerve in contrast to idiopathic CTS. ${ }^{[1-3]}$

There were statistically significant positive correlations between the clinical stages of the patients and the age, working duration and duration of symptoms in our study. A statistically significant positive correlation was also present between the neurophysiologic grades of the patients and the duration of symptoms in our study (Table II).

Many studies about occupational factors related to CTS in different geographic, sociocultural and industrial domains are present in the literature. ${ }^{[6-9,18,20,24]}$ Carpal tunnel syndrome and shoulder impingement syndrome were found significantly more frequent among betel pepper cullers in a study comparing the proportion of cumulative trauma disorders between cullers and those with other occupations in Taiwan. The authors thought that these disorders might have resulted from a prolonged static posture and repetitive motions while culling the leaves ${ }^{[9]}$ Kutluhan et al ${ }^{[6]}$ have studied the relationship between CTS development and employment duration and stated that women working in the hand-made carpet industry have a higher risk of CTS development. The results of this study showed that employment duration and work produced per year were weak but significant risk factors for CTS development in carpet workers. Kouyoumdjian et al. ${ }^{[1]}$ investigated the relation between CTS and manual milking and found that manual milking represents a major and very specific risk factor mainly in countries where milking machines are not yet in common use. The authors have stated that manual milking requires powerful and repetitive use of finger flexor muscles and concluded that manual milking could be a natural model for occupational CTS.

All of the patients in the study group were admitted to hospital with symptoms of neural entrapment of the median nerve, which started or worsened after heavy 
duty in the tea fields. In our study group we found that CTS was more severe in terms of clinical and neurophysiological findings in older patients having longer duration of symptoms and working history. In contrast to idiopathic CTS, predominance of the motor nerve conduction abnormality instead of sensory nerve conduction in the entire group was thought an unusual neurophysiological finding which may explain the pathophysiology of CTS related to manual tea harvesting. Symptom severity scores and functional status of the patients were improved significantly after surgical decompression of the median nerve in the carpal tunnel. The patients were able to return to hard work six weeks after surgery.

The relationship between manual tea harvesting and development of work-related CTS among tea harvesters treated surgically was presented in this study. Unfortunately our study has some limitations. The absence of longer follow-up period and the absence of a control group appear to be the most important ones.

In conclusion, manual harvesting of tea is an occupational risk factor for development of occupation related CTS. Daily working duration and the years spent working in tea fields should be shortened in order to decrease the risk of CTS development among workers in manual tea harvesting. Surgery plays an important role in the relief of the symptoms and permanent nerve damage. Decompression of the median nerve should be considered in patients where symptoms related to CTS appear or increase in the tea harvesting period.

\section{Declaration of conflicting interests}

The authors declared no conflicts of interest with respect to the authorship and/or publication of this article.

\section{Funding}

The authors received no financial support for the research and/or authorship of this article.

\section{REFERENCES}

1. Kouyoumdjian JA, de Araújo RG. Carpal tunnel syndrome and manual milking: nerve conduction studies in 43 cases. Arq Neuropsiquiatr 2006;64:747-9.

2. Yagev Y, Gringolds M, Karakis I, Carel RS. Carpal tunnel syndrome: under-recognition of occupational risk factors by clinicians. Ind Health 2007;45:820-2.

3. Roquelaure $\mathrm{Y}, \mathrm{Ha}$ C, Nicolas G, Pélier-Cady MC, Mariot C, Descatha A, et al. Attributable risk of carpal tunnel syndrome according to industry and occupation in a general population. Arthritis Rheum 2008;59:1341-8. doi: 10.1002/art.24002.

4. Einhorn N, Leddy JP. Pitfalls of endoscopic carpal tunnel release. Orthop Clin North Am 1996;27:373-80.
5. Cirpar M, Arı M, Türker M, Ekşioğlu MF, Cetik O. The efficacy and safety of limited incision technique in carpal tunnel release. [Article in Turkish] Eklem Hastalik Cerrahisi 2011;22:33-8.

6. Kutluhan S, Akhan G, Demirci S, Duru S, Koyuncuoglu HR, Ozturk M, et al. Carpal tunnel syndrome in carpet workers. Int Arch Occup Environ Health 2001;74:454-7.

7. Maghsoudipour M, Moghimi S, Dehghaan F, Rahimpanah A. Association of occupational and non-occupational risk factors with the prevalence of work related carpal tunnel syndrome. J Occup Rehabil 2008;18:152-6. doi: 10.1007/ s10926-008-9125-4.

8. Shiri R, Miranda H, Heliövaara M, Viikari-Juntura E. Physical work load factors and carpal tunnel syndrome: a population-based study. Occup Environ Med 2009;66:36873. doi: 10.1136/oem.2008.039719.

9. Wang LY, Pong YP, Wang HC, Su SH, Tsai CH, Leong CP. Cumulative trauma disorders in betel pepper leaf-cullers visiting a rehabilitation clinic: experience in Taitung. Chang Gung Med J 2005;28:237-46.

10. Padua L, LoMonaco M, Gregori B, Valente EM, Padua R, Tonali P. Neurophysiological classification and sensitivity in 500 carpal tunnel syndrome hands. Acta Neurol Scand 1997;96:211-7.

11. Padua L, Padua R, Lo Monaco M, Aprile I, Tonali P. Multiperspective assessment of carpal tunnel syndrome: a multicenter study. Italian CTS Study Group. Neurology 1999;53:1654-9.

12. Sezgin M, Incel NA, Serhan S, Camdeviren H, As I, Erdoğan C. Assessment of symptom severity and functional status in patients with carpal tunnel syndrome: reliability and functionality of the Turkish version of the Boston Questionnaire. Disabil Rehabil 2006;28:1281-5.

13. Levine DW, Simmons BP, Koris MJ, Daltroy LH, Hohl GG, Fossel AH, et al. A self-administered questionnaire for the assessment of severity of symptoms and functional status in carpal tunnel syndrome. J Bone Joint Surg Am 1993;75:1585-92.

14. Rodner CM, Katarincic J. Open carpal tunnel release. Techniques in Orthopedics 2011;21:3-11.

15. Stewart JD. Peripheral nerve fascicles: anatomy and clinical relevance. Muscle Nerve 2003;28:525-41.

16. Aroori S, Spence RA. Carpal tunnel syndrome. Ulster Med J 2008;77:6-17.

17. Lewis C, Mauffrey C, Newman S, Lambert A, Hull P. Current concepts in carpal tunnel syndrome: a review of the literature. Eur J Orthop Surg Traumatol 2010;20:445-52.

18. Hagberg M, Morgenstern H, Kelsh M. Impact of occupations and job tasks on the prevalence of carpal tunnel syndrome. Scand J Work Environ Health 1992;18:337-45.

19. Bağatur EA, Dervişoğlu S, Albayrak M, Doğan A, Mumcuoğlu İE, Zorer G. İdiyopatik karpal tünel sendromlu hastalarda transvers karpal ligaman ve fleksör tenosinovyum örneklerinde histopatolojik çalışma. Eklem Hastalik Cerrahisi 2006;17:72-8.

20. Barcenilla A, March LM, Chen JS, Sambrook PN. Carpal tunnel syndrome and its relationship to occupation: a meta-analysis. Rheumatology (Oxford) 2012;51:250-61. doi: 10.1093/rheumatology/ker108.

21. Conolly WB, McKessar JH. Carpal tunnel syndromecan it be a work related condition? Aust Fam Physician 2009;38:684-6. 
22. Schuind F, Ventura M, Pasteels JL. Idiopathic carpal tunnel syndrome: histologic study of flexor tendon synovium. J Hand Surg Am 1990;15:497-503.

23. Rempel D, Dahlin L, Lundborg G. Pathophysiology of nerve compression syndromes: response of peripheral nerves to loading. J Bone Joint Surg Am 1999;81:1600-10.

24. Armstrong T, Dale AM, Franzblau A, Evanoff BA. Risk factors for carpal tunnel syndrome and median neuropathy in a working population. J Occup Environ Med 2008;50:135564. doi: 10.1097/JOM.0b013e3181845fb1. 